\title{
Chemical studies and utilization of Tamarindus indica and its seeds in some technological application
}

\author{
Asma A. El-Gindy; Mona E. Youssif and Youssif, M.R.G. \\ Food Technology Research Institute, Agricultural Research Center, Giza, Egypt.
}

\begin{abstract}
Tamarind is a nutritious fruit with a variety of uses. The properties of this species have been extensively studied, particularly with reference to the components of the seed. The study revealed that the seed is rich in proteins (13.6\%) while the seed coat is rich in fibers (21.6\%). The seed has high content of calcium, phosphorus, magnesium, potassium, copper, zinc and manganese $(190,155,113,510,13,2.3$ and $1.1 \mathrm{mg} / 100 \mathrm{~g})$ respectively compared with pulp. The total content of phenolics of $T$. indica L. seeds was high180.1 milligram gallic acid equivalent per gram of dry weight (mg GAE $\mathrm{gDW}^{-1}$ ). Also, total flavonoid content was high for $T$. indica L. seeds 164.4 milligram catechin equivalents per gram dry weight ( $\mathrm{mg} \mathrm{CE} \mathrm{gDW}^{-1}$ ). Total phenolic content, total flavonoid content and total antioxidant activity of tamarind pulp soaked with different concentrations of tamarind seed powder showed an increase compared with control (tamarind soaked without TSP). Also, addition of tamarind seed powder to tamarind soaked to level of $2.0 \%$ (w/v) did not result in any significant difference in the perceived sensory attributes of tamarind pulp and seed soaked $(p>0.05)$ as compared to the control tamarind soaked without tamarind seed powder). But, the content of moisture, protein, crude fiber and ash in tamarind seeds by-products substituted biscuits increased with increased level of addition of tamarind seeds flour to biscuits. Also, the total calcium, phosphorus, magnesium, potassium, copper, zinc and iron in tamarind seeds byproducts substituted biscuits increased with the increased level of addition of tamarind seeds flour to biscuits. The mean values of physical characteristics of wheat biscuit and fortified wheat biscuits with Tamarind seeds flour showed that gradual increment of spread ratio of fortified biscuits with three studied tamarind seeds flour ranging from 5.22 to 5.30 for 3, $6 \%$ tamarind seeds flour supplemented biscuits and $9 \%$. That sensory evaluation of seeds tamarind by-products substituted biscuits containing different levels of tamarind seeds improvement with the increased level of addition of tamarind seeds to biscuits from 3 until 12\% compared to the control biscuit for all organoleptic characteristics. Total phenolic content, total flavonoid content and total antioxidant activity of seeds tamarind by-products substituted biscuits increased with the increased levels of addition.
\end{abstract}

Keywords: Tamarind seed - Tamarind pulp - Total phenolic - Total flavonoid and total antioxidant activity - Tamarind soaked - Biscuits

\section{Introduction}

Tamarind (Tamarindus indica L.) is a member of the dicotyledonous family fabaceae (Leguminosae) (Chant, 1993). It grows in more than 50 countries of the world. The major areas of production are in Asian countries like India, Bangladesh, Sri Lanka Thailand, and Indonesia, and in the African and the American continents. The tamarind tree is a long-lived, large evergreen or semi-green tree, grows wild, though cultivated to a limited extent. A mature tree may attain 
a maximum height of 30 meter (Jambulingam and Fernandes, 1986; Stross, 1995). The tamarind tree has the ability to grow in poor soils because of their nitrogen fixing capability and withstanding long periods of drought makes them ideal low input, high yielding trees (Felker, 1981; Felker and Clark, 1980). Tamarind is a multipurpose tree species; almost every part of it finds some use. The fruit contains about 55\% pulp, 34\% seed, and $11 \%$ shell, and the fiber in a pod (Rao and Srivastava, 1974). The pulp of the fruit contains organic acids: Tartaric (3-10\%), acetic, citric, formic, malic, succinic acid; amino acids (alanine, leucin, phenylalanine, prolin, serine), invert sugar (25-30\%), pectin, protein (87,9 $\mathrm{g} / \mathrm{kg}$ ), fat $(19,1 \mathrm{~g} / \mathrm{kg})$, some pyrazines, trans-2-hexenal, and some thiazoles (2- ethylthiazole, 2-methylthiazole) as fragrant (Hänsel et al. 1992). Popenoe (1974) found the pulp of the fruit to be very rich in vitamin $C$ and sugar. Hence it is used in syrups, juice concentrates, curries, pickles and meat sauces. The sugar in it is mainly glucose and fructose. Tamarind pulp is widely consumed in many countries around the world. It is often made into juice, infusion or brine though there are many different recipes. In some African countries, the pulp juice is mixed with wood ash to neutralize the sour taste of the tartaric acid, but the common method is to add sugar to make a pleasantly acid drink; the pulp is often eaten raw and sweetened with sugar (Lotschert and Reese, 1994).

The seed comprises the seed coat or testa (25-30\%) and the kernel or endosperm (70-75\%) (Coronel, 1991 and Shankaracharya, 1998). Tamarind seed is the raw material used in the manufacture of tamarind seed kernel powder (TKP), polysaccharide (jellose), adhesive and tannin. The seeds are also used for other purposes and are presently gainmg importance as an alternative source of protein, rich in some essential ammo acids. Unlike the pulp the seed is a good source of protein and oil. There has been considerable interest amongst chemists, food technologists and nutritionist's the study of the properties of tamarind seeds. Recent work on stabilisation of xyloglucans of the tamarind seed polysaccharide and the gelling behaviour of polyose from tamarind kernel powder so that pectin/polyose mixes can be recommended (Marathe et al., 2002).

The fruits are reported to have anti-fungal and anti-bacterial properties (John et al., 2004). Both the pulp and fruit extracts have been shown enhancing the bioavailability of ibuprofen in human (Garba et al., 2003). Frequent researches on aqueous extracts of seeds have shown a strong anti-diabetic effect in rats (Maiti et al., 2004). Tamarind seed coat, a byproduct of the tamarind gum industry, could be used as a safe and low cost source of anti-oxidant, although other herbs may be more effective (Ramos et al., 2003).

Extraction of antioxidant compounds from the seed coat of sweet Thai tamarind was reported by Luengthanaphol et al. (2004) as well as crude tamarind seed coat extracts were stable following heat treatment at $100^{\circ} \mathrm{C}$ for two hours. Anti-oxidative activity of the extracts was lower at $\mathrm{pH} 5.0$ than at $\mathrm{pH} 3.0$ or 7.0 . This study therefore developed an improved process, which is simple and affordable, for the production of juice type beverage, and biscuit with improved quality attributes, from tamarind fruits.

The aim of this study was undertaken to analyze the phenolic content and antioxidant activity of tamarind (pulp and seeds). In addition, the potential of using certain traditional food additives in enhancing the natural antioxidant activity of food was evaluated. 


\section{Egypt. J. of Nutrition and Health Vol. 10 No. 1 (2015)}

\section{Materials and Methods}

\section{Materials}

Fresh matured tamarind fruits were obtained from local supplier in Cairo, Egypt, where it was originally coming from the arid Aswan desert in Southern Egypt. Wheat flour $72 \%$ extraction hard red winter was obtained from ElHaram Milling Company, Faesal, Giza. Sugar powder, corn oil, sodium chloride, ammonium bicarbonate, and rose oil were purchased from Cairo local market.

\section{Technological Process:}

Plant material:

The pulp of the fruits was hand-scraped from the seeds, and was there after stored in freezer at $-20^{\circ} \mathrm{C}$ prior to analysis. Seeds cleaned and dried under shade at ambient temperature of about $25^{\circ} \mathrm{C}$. Separating the shell from kernel of seeds tamarind is the hardest phase because shell (testa) is closely tied to endosperm. One separation alternative is by roasting in $150^{\circ} \mathrm{C}$ for 15 minutes to make it brittle and then easy to separate according to (Gerard, 1980) The seeds were milled into fine flour (tamarind and seed powder, (TSP) using the Wonder Mill grain mill (Grote Molten Inc, Pocatello, ID, USA), sieved through a $200 \mu \mathrm{m}$ sieve size and stored in airtight plastic containers at $4^{\circ} \mathrm{C}$ until further use.

Preparation of mixture of tamarind pulp and seed powder soaked:

Tamarind pulp soaked was prepared by first stirring $295 \mathrm{~g}$ of tamarind fruit into one liter of cold water while stirring for about $30 \mathrm{~min}$ and discarding all the seeds and fibers. The resulting pulp soaked was filtered through cheese cloth to obtain a volume about $(900 \mathrm{ml})$ equal volume of water and $120 \mathrm{~g}$ of sugar added to sweeten thereafter, the sweetened soaked was further divided into five equal portions. Tamarind seed powder (TSP) was added to levels of $1,2,3$ and $4 \%(w / v)$ to each of the respective first, second, third and fourth portions of the sweetened tamarind soaked. All portions were heated to boiling point to facilitate extraction of phenolic compounds from the seed powder and the mixture was filtered through cheese cloth to obtain the final tamarind pulp and seed powder soaked the remaining fifth portion of the sweetened tamarind soaked containing no tamarind seed powder (O\%TSP) was used as a control.

\section{Preparation of Biscuit:}

Biscuit formula and ingredients control biscuit dough was prepared according to (Nwosu, 2013). With some modification, the formula presented in table (1), the flour used for biscuit production was from blends of wheat flour and ground tamarind seeds flour. The flour was obtained by blending in the ratio of $(100: 0 ; 97: 3 ; 94: 6 ; 91: 9 ; 88: 12 ;$ and 85:15 (wheat flour: ground tamarind seeds). 
Table (1):

Biscuit formula

\begin{tabular}{|l|c|}
\hline \multicolumn{1}{|c|}{ Ingredients } & \multicolumn{1}{|c|}{ Amount (g) } \\
\hline Flour (wheat flour: ground tamarind seeds) & 100.00 \\
\hline Powdered sugar & 25.00 \\
\hline Corn oil & 25.00 \\
\hline Sodium chloride & 1.00 \\
\hline Ammonium carbonate & 1.00 \\
\hline Rose oil & 0.01 (one drop) \\
\hline Water & 20.00 \\
\hline
\end{tabular}

Methods:

Physical evaluation of biscuits:

Biscuits were evaluated for height $(\mathrm{cm})$, width $(\mathrm{cm})$, spread ratio and spread factor. Volume $\left(\mathrm{cm}^{3}\right)$, weight $(\mathrm{g})$, specific volume $\left(\mathrm{cm}^{3} / \mathrm{g}\right)$ five biscuits were used for the evaluations from each of the five studied biscuits and averages were recorded. The spread ratio, spread factor and specific volume were calculated according to Manohar and Rao (1997) using the following equations:

Spread ratio $=$ Width $/$ Height

Spread factor $=$ Spread ratio of sample $/$ Spread ratio of control

Specific volume $=$ volume $/$ weight

Sensory evaluation of biscuit samples and tamarind pulp and seed powder soaked:

Sensory characteristics of biscuits samples were delivered to ten panelists after one hour of baking according to (Austin, and Ram, 1971), Sensory evaluation of the tamarind pulp and seed powder soaked determined as described by (Larmond, 1977).

\section{Determination of Mineral Contents:}

The minerals contents i.e. (sodium, potassium, magnesium, calcium, iron, copper, zinc, manganese, nickel and phosphorus of tamarind pulp, seed, kernel and testa, wheat biscuits and fortified wheat biscuits with tamarind seeds powder were determined according to the methods described in AOAC (1997). The samples were wet acid digested using a nitric acid and perchloric acid mixture ( $\mathrm{HNO}, \mathrm{HCLO} 4,2: 1 \mathrm{v} / \mathrm{v}$ ) according to the method described by Chapman and Pratt (1978). The amounts of iron, zinc, copper, nickel, and manganese in the digested sample were determined using a GBC Atomic Absorption $906 \mathrm{~A}$ as described in AOAC (1997). Sodium and potassium were determined by flame photometer 410. Calcium and magnesium were determined using Double Beam Atomic Absorption. Phosphorus was determined according to the method described in AOAC (1997).

\section{Determination of Chemical Composition:}

Moisture, protein, crude fibers and ash contents were determined according to the method described in the AOAC (1997). Fat content was determined as the ether extract according to AOCS (1994). Total carbohydrates were calculated by difference according to Pellet and Sossy (1970). All determinations were performed in triplicates and the means were reported. The caloric value was calculated using values of $4 \mathrm{kcal} / \mathrm{g}$. of protein, $4 \mathrm{kcal} / \mathrm{g}$. of carbohydrate and $9 \mathrm{kcal} / \mathrm{g}$. of fat according to Livesy (1995). Total free phenolic compounds content was determined using Folin-Ciocalteu 


\section{Egypt. J. of Nutrition and Health Vol. 10 No. 1 (2015)}

reagent according to the method described by Danial and George (1979). Flavonoids content was determined using the method of Jia et al. (1999). Total antioxidant activity was determined using the method described by Andabati and Muyonga (2014).

Statistical Analysis:

Data were assessed by analysis of variance (ANOVA) as outlined by (Sendecor and Cochran, 1987).

\section{Results and Discussion}

Table (2):

Chemical composition of tamarind seed, kernel, and testa.

\begin{tabular}{|l|l|l|l|l|}
\hline \multicolumn{1}{|c|}{$\begin{array}{c}\text { *Chemical composition } \\
(\%)\end{array}$} & \multicolumn{1}{|c|}{ Tamarind pulp } & \multicolumn{1}{c|}{ Whole seed } & \multicolumn{1}{c|}{ Seed kernel } & \multicolumn{1}{c|}{$\begin{array}{c}\text { Testa } \\
\text { (seed coat) }\end{array}$} \\
\hline Moisture & $29.2 \pm 2.1$ & $11.5 \pm 1.3$ & $11.5 \pm 0.5$ & $11.1 \pm 0.8$ \\
\hline Protein & $2.8 \pm 0.4$ & $13.6 \pm 1.1$ & $18.5 \pm 1.2$ & -- \\
\hline Oil & $0.15 \pm 0.05$ & $5.3 \pm 1.0$ & $6.6 \pm 0.9$ & -- \\
\hline Crude fiber & $5.6 \pm 0.6$ & $7.6 \pm 1.2$ & $3.2 \pm 0.8$ & $21.6 \pm 0.5$ \\
\hline Ash & $3.7 \pm 0.4$ & $4.3 \pm 0.9$ & $2.4 \pm 0.6$ & $7.5 \pm 0.8$ \\
\hline Tannin & --- & $6.5 \pm 0.3$ & --- & $19.7 \pm 1.1$ \\
\hline${ }^{* *}$ Carbohydrates & $58.5 \pm 0.9$ & $57.7 \pm 0.6$ & $57.8 \pm 1.1$ & $40.1 \pm 0.8$ \\
\hline Calories/100g & $246.0 \pm 0.9$ & $306.4 \pm 2.1$ & $331.6 \pm 0.9$ & -- \\
\hline
\end{tabular}

* Means of triplicate \pm SD.

** Calculated by difference.

The chemical composition of the whole seed, the kernel, and testa are shown in Table (2). The whole seed is rich in proteins $(13.6 \pm 1.1 \%)$ while the seed coat is rich in fibers $(21.6 \pm 0.5 \%)$. Shankaracharya (1998) mentioned that, the whole seed contains $13.1 \mathrm{~g}$ crude protein, $67.1 \mathrm{~g}$ crude fiber, $48.2 \mathrm{~g}$ crude fat, and $56.2 \mathrm{~g}$ tannins per kg of seed and trypsin inhibitor activity (TIA) of 10.8. The trypsin inhibitor, activity is higher in the pulp than in the seed, but both are heat labile. The seeds are an important source of protein and valuable amino acids.

Table (3):

Mineral content of tamarind pulp, seed, kernel, and testa $(\mathrm{mg} / 100 \mathrm{~g})$.

\begin{tabular}{|l|l|l|l|l|}
\hline \multicolumn{1}{c|}{$\begin{array}{c}\text { Mineral content } \\
(\mathrm{Mg} / 100 \mathrm{~g})\end{array}$} & \multicolumn{1}{c|}{ Pulp } & \multicolumn{1}{c|}{ Kernel } & \multicolumn{1}{c|}{ Testa } \\
\hline Calcium & $185 \pm 1.2$ & $190 \pm 0.9$ & $122 \pm 0.6$ & $99 \pm 1.2$ \\
\hline Phosphorus & $112 \pm 0.9$ & $155 \pm 1.3$ & $102 \pm 0.7$ & $92 \pm 0.9$ \\
\hline Magnesium & $53 \pm 0.8$ & $113 \pm 0.6$ & $177 \pm 0.6$ & $119 \pm 0.8$ \\
\hline Sodium & $66 \pm 1.2$ & $15 \pm 0.4$ & $205 \pm 0.9$ & $234 \pm 0.6$ \\
\hline Potassium & $322 \pm 1.1$ & $510 \pm 1.3$ & $1009 \pm 0.6$ & $235 \pm 1.2$ \\
\hline Copper & $1.1 \pm 0.3$ & $13 \pm 0.4$ & $5 \pm 0.3$ & $3 \pm 0.1$ \\
\hline Zinc & $1.5 \pm 0.1$ & $2.3 \pm 0.3$ & $1.01 \pm 0.1$ & $1.23 \pm 0.3$ \\
\hline Iron & $8.3 \pm 0.4$ & $5.9 \pm 0.7$ & $60 \pm 0.8$ & $50 \pm 0.9$ \\
\hline Nickel & $0.6 \pm 0.1$ & --- & -- & -- \\
\hline Manganese & $0.7 \pm 0.3$ & $1.1 \pm 0.1$ & $3 \pm 0.4$ & $2 \pm 0.4$ \\
\hline
\end{tabular}

Mineral content of tamarind pulp, seed, kernel, and testa $(\mathrm{mg} / 100 \mathrm{~g})$ are shown in Table (3). The seed has higher content of calcium, phosphorus, magnesium, potassium, copper, zinc and manganese (190 $\pm 0.9,155 \pm 1.3$, 
$113 \pm 0.6,510 \pm 1.3,13 \pm 0.4,2.3 \pm 0.3$ and $1.1 \pm 0.1 \mathrm{mg} / 100 \mathrm{~g})$ respectively compared with pulp $(185 \pm 1.2,112 \pm 0.9,53 \pm 0.8$, $322 \pm 1.1,1.1 \pm 0.3,1.5 \pm 0.1$ and $0.7 \pm 0.3 \mathrm{mg} / 100 \mathrm{~g}$ ) respectively. However the pulp has high content of sodium and iron $(66 \pm 1.2$ and $8.3 \pm 0.4 \mathrm{mg} / 100 \mathrm{~g})$ respectively compared with seeds $(15 \pm 0.4$ and $5.9 \pm 0.7 \mathrm{mg} / 100 \mathrm{~g})$ respectively. Bhattacharya et al., (1994) they found that, the edible seed kernel is rich in phosphorus, potassium and magnesium.

Table (4):

Total phenolic content (TPC), total flavonoid content (TFC) and total antioxidant activity (TAC) of tamarind seeds.

\begin{tabular}{|c|c|c|}
\hline $\begin{array}{c}\text { TPC } \\
(m g \text { GAE gDW }\end{array}$ & $\begin{array}{c}\text { TFC } \\
\left(\mathrm{mg} \mathrm{CE} \mathrm{gDW}^{-1}\right)\end{array}$ & $\begin{array}{c}\text { TAC } \\
\left(\mathrm{mg} \mathrm{VE}^{-1} \mathrm{gWW}^{-1}\right)\end{array}$ \\
\hline $180.1 \pm 5.2$ & $164.4 \pm 2.3$ & $55.6 \pm 2.4$ \\
\hline
\end{tabular}

The total phenolic content of $T$. indica L. seeds was high180.1 mg GAE gDW ${ }^{-1}$. Table (4), this result agrees with that obtained by Andabati and Muyonga (2014) they mentioned that, the total content of phenolic of the different foods ranged from 2.6 to $184.2 \mathrm{mg} \mathrm{GAE} \mathrm{gDW} \mathrm{mb}^{-1}$ and was highest for $T$. indica $\mathrm{L}$. seeds and lowest for Amaranthus hypochondriacus L. The result in Table (4) also showed that, total flavonoid content was high for $T$. indica L. being $164.4 \mathrm{mg} \mathrm{CE} \mathrm{gDW}^{-1}$. This result agrees with Andabati and Muyonga (2014) Total flavonoid content was highest for T.indica L. seeds $162.2 \mathrm{mg} \mathrm{CE} \mathrm{gDW}{ }^{-1}$ and lowest for Amaranthus hypochondriacus L. (2.6 mg CE gDW'-1). Flavonoids are a large class of polyphenolic compounds that have been attributed to nutraceutical properties of several plants. Flavonoids are potent antioxidants and metal chelators (Tapas et al., 2008) and have long been recognized to be beneficial against many chronic diseases such as cardiovascular diseases (Kris-Etherton et al., 2002), cancer (Birt et al., 2001) inflammation (Manthey et al., 2001) and neurodegenerative disorders (Lu et al., 2010). Also, the content of

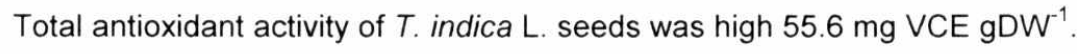

Table (5):

Total phenolic content, total flavonoid content and total antioxidant activity of tamarind pulp soaked with different concentrations of tamarind seed powder.

\begin{tabular}{|c|c|c|c|}
\hline $\begin{array}{c}\text { Tamarind seed powder } \\
\text { concentration } \\
(\%)\end{array}$ & 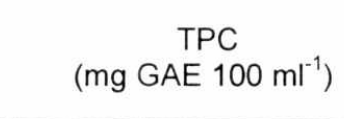 & 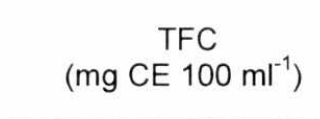 & $\begin{array}{c}\text { TAC } \\
\left(\mathrm{mg} \mathrm{VCE} 100 \mathrm{ml}^{-1}\right)\end{array}$ \\
\hline 0 & $23.55 \pm 1.2$ & $0.94 \pm 0.1$ & $7.80 \pm 0.4$ \\
\hline 1 & $37.15 \pm 0.3$ & $12.11 \pm 0.7$ & $14.22 \pm 0.3$ \\
\hline 2 & $48.21 \pm 1.3$ & $13.9 \pm 0.6$ & $19.44 \pm 1.2$ \\
\hline 3 & $54.33 \pm 0.7$ & $17.03 \pm 1.3$ & $18.01 \pm 0.7$ \\
\hline 4 & $61.33 \pm 1.2$ & $19.24 \pm 0.6$ & $21.22 \pm 0.4$ \\
\hline
\end{tabular}

Total phenolic content of the Tamarindus indica L. pulp and tamarind seed soaked incorporation of tamarind seed powder (TSP) into tamarind pulp soaked are shown in Table (5). There is proportionate increase in total phenolic

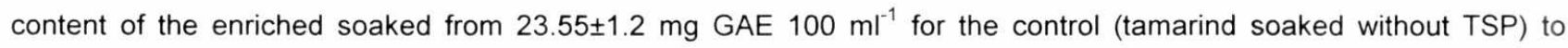

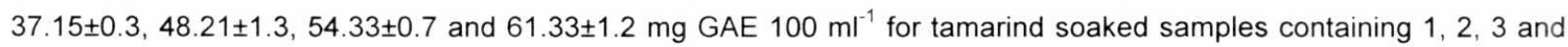
$4 \%$ TSP, respectively. The total flavonoid content (TFC), showed a similar pattern, increasing from $0.94 \pm 0.1 \mathrm{mg}$ CE 100 


\section{Egypt. J. of Nutrition and Health Vol. 10 No. 1 (2015)}

$\mathrm{ml}^{-1}$ for the control to $12.11 \pm 0.7,13.9 \pm 0.6,17.03 \pm 1.3$ and $19.24 \pm 0.6 \mathrm{mg} \mathrm{CE} 100 \mathrm{ml}^{-1}$ for tamarind soaked samples enriched with 1, 2, 3 and $4 \%(\mathrm{w} / \mathrm{v}) \mathrm{TSP}$, respectively. Similarly, total antioxidant activity increased from 7.80 $\pm 0.4 \mathrm{mg}$ VCE $\mathrm{ml}^{-1}$ for the control to $14.22 \pm 0.3,19.44 \pm 1.2,18.01 \pm 0.7$ and $21.22 \pm 0.4 \mathrm{mg} \mathrm{VCE} 100 \mathrm{ml}^{-1}$ for the tamarind pulp soaked sample containing 1, 2, 3 and $4 \%(w / v)$ TSP, respectively. The phenolic contents of tamarind soaked samples enriched with tamarind seed powder were comparatively higher than those of natural fresh juices made from apricot (23.75), pineapple (36.16), white grape (37.69), apple (45.38) and red grape juices (49.4), as reported by Mahdavi et al. (2010). Siddhuraju (2007) who showed similar results they demonstrated that incorporation of tamarind seed powder boosted the content of phenolic compounds and antioxidant activity of tamarind pulp juice. They also showed that, the phenolic content and antioxidant activity increased proportionately with the amount of tamarind seed powder incorporated in the tamarind soaked However, the extent of incorporating tamarind seed powder in soaked might be limited by the high content of tannins in tamarind seed coat and associated astringency (Pugalenthi et al., 2004). Thus, pre-treatment methods such as autoclaving of the seeds were found to reduce the astringency associated with tamarind seed (Legesse and Emire, 2012).

Table (6):

Sensory evaluation of tamarind soaked prepared from tamarind pulp and seed powder

\begin{tabular}{|l|l|l|l|l|l|}
\hline $\begin{array}{c}\text { Tamarind } \\
\text { seed powder } \\
\text { concentration (\%) }\end{array}$ & \multicolumn{1}{|c|}{ Color } & \multicolumn{1}{c|}{ Aroma } & \multicolumn{1}{|c|}{ Taste } & \multicolumn{1}{c|}{ Mouth feel } & \multicolumn{1}{c|}{$\begin{array}{c}\text { General } \\
\text { acceptability }\end{array}$} \\
\hline 0 & $9.0 \pm 0.3^{A}$ & $8.8 \pm 0.5^{A}$ & $8.7 \pm 0.2^{A}$ & $9.2 \pm 0.3^{A}$ & $8.9 \pm 0.3^{A}$ \\
\hline 1 & $8.7 \pm 0.2^{A}$ & $9.0 \pm 0.2^{A}$ & $8.5 \pm 0.3^{A}$ & $9.0 \pm 0.1^{A}$ & $8.7 \pm 0.3^{A}$ \\
\hline 2 & $8.0 \pm 0.3^{B}$ & $8.5 \pm 0.2^{B}$ & $8.2 \pm 0.1^{A}$ & $8.5 \pm 0.2^{B}$ & $8.5 \pm 0.2^{A}$ \\
\hline 3 & $6.2 \pm 0.1^{C}$ & $6.2 \pm 0.3^{C}$ & $6.3 \pm 0.2^{B}$ & $6.50 \pm 0.3^{C}$ & $6.3 \pm 0.2^{B}$ \\
\hline 4 & $5.2 \pm 0.1^{D}$ & $5.3 \pm 0.2^{D}$ & $5.1 \pm 0.5^{C}$ & $5.2 \pm 0.2^{D}$ & $5.2 \pm 0.2^{C}$ \\
\hline LSD & 0.3986 & 0.4305 & 0.5335 & 0.4228 & 0.4456 \\
\hline
\end{tabular}

Table (6) shows sensory evaluation of tamarind pulp and seed soaked. The obtained results show that, addition of tamarind seed powder to tamarind soaked at level of $2.0 \%(\mathrm{w} / \mathrm{v})$ did not result in any significant difference in the perceived sensory attributes of tamarind pulp and seed soaked ( $p>0.05)$ compared to the control soaked without tamarind seed powder. However, incorporation of tamarind seed powder at level of 3 and $4 \%$ (w/v) in the tamarind soaked resulted in reduced scores in all the sensory attributes such as color, aroma, taste and mouth feel. The largest difference in sensory scores between the control tamarind soaked and tamarind soaked containing 3 and $4 \%$ tamarind seed powder was in aroma and consistency implying that the tamarind seeds disproportionately affected these sensory attributes. Tamarind seed kernels are known to contain some polysaccharides which when mixed with water form mucilaginous dispersions, leading to increase in viscosity of the soaked. Furthermore, the presence of antinutritional factors such as tannins in tamarind seed testa renders the whole seed unsuitable for consumption (Caluwe et al., 2010). Overall, the color, aroma and consistency of 1 and $2 \%$ tamarind pulp and seed powder soaked were well accepted and the respective general acceptability scores for these were $8.7 \pm 0.3$ and $8.5 \pm 0.2$.

The chemical compositions of tamarind seeds by-products substituted biscuits $\mathrm{g} / 100 \mathrm{~g}$ (on dry weight basis) are shown in Table (7). The content of moisture, protein, crude fiber and ash increased with the increase in the level of substitution of tamarind seeds to biscuits. The highest level of moisture, protein, crude fiber and ash $(7.82 \pm 0.2$, $11.62 \pm 1.4,3.79 \pm 0.3$ and $1.43 \pm 0.2 \mathrm{mg} / 100 \mathrm{~g}$ ), respectively in tamarind seeds by-products substituted biscuits with $15 \%$ 
level of substitution of tamarind seeds to biscuits. However, the content of carbohydrates decreased with increased level of substitution of tamarind seeds to biscuits.

Table (7):

Chemical composition of tamarind seeds by-products substituted biscuits $\mathrm{g} / 100 \mathrm{~g}$ (on dry weight basis)*

\begin{tabular}{|c|c|c|c|c|c|c|}
\hline $\mathrm{C}_{\text {Composition }}^{\mathrm{Sa}}$ & 1 & 2 & 3 & 4 & 5 & 6 \\
\hline Moisture & $5.53 \pm 0.5$ & $6.42 \pm 0.2$ & $6.83 \pm 0.2$ & $7.22 \pm 0.6$ & $7.53 \pm 0.3$ & $7.82 \pm 0.2$ \\
\hline Protein & $9.84 \pm 0.4$ & $10.01 \pm 0.6$ & $10.40 \pm 0.6$ & $10.75 \pm 0.3$ & $11.2 \pm 0.2$ & $11.62 \pm 1.4$ \\
\hline Oil & $20.25 \pm 0.2$ & $19.79 \pm 0.7$ & $19.95 \pm 0.6$ & $20.11 \pm 0.4$ & $20.25 \pm 0.8$ & $20.41 \pm 1.4$ \\
\hline Crude fiber & $2.72 \pm 0.5$ & $2.87 \pm 0.4$ & $3.10 \pm 0.2$ & $3.33 \pm 0.5$ & $3.56 \pm 0.4$ & $3.79 \pm 0.3$ \\
\hline Ash & $0.80 \pm 0.2$ & $0.91 \pm 0.2$ & $1.04 \pm 0.1$ & $1.17 \pm 0.3$ & $1.30 \pm 0.2$ & $1.43 \pm 0.2$ \\
\hline Carbohydrates ${ }^{\star \star}$ & $60.82 \pm 1.2$ & $60.00 \pm 0.5$ & $58.70 \pm 0.8$ & $57.44 \pm 0.6$ & $56.16 \pm 0.4$ & $54.93 \pm 0.5$ \\
\hline
\end{tabular}

${ }^{*}$ Mean of three replicates.

${ }^{\star \star}$ Calculated by difference.

1- $100 \%$ wheat flour $72 \%$ extraction biscuits (control).

2- $3 \%$ tamarind seeds powder supplemented biscuits.

3- $6 \%$ tamarind seeds powder supplemented wheat biscuits.

4- $9 \%$ tamarind seeds powder supplemented wheat biscuits.

5- 12 tamarind seeds powder supplemented wheat biscuits.

6- $15 \%$ tamarind seeds powder supplemented wheat biscuits.

Table (8):

Mineral composition of tamarind seeds by-products substituted biscuits $\mathrm{g} / 100 \mathrm{~g}$ on dry weight basis

\begin{tabular}{|l|l|l|l|l|l|l|}
\hline \multicolumn{1}{|c|}{ Samples } & \multicolumn{1}{|c|}{1} & \multicolumn{1}{c|}{2} & \multicolumn{1}{c|}{3} & \multicolumn{1}{c|}{3} & \multicolumn{1}{c|}{4} & \multicolumn{1}{c|}{5} \\
\hline Calcium & $21.00 \pm 0.4$ & $24.37 \pm 1.3$ & $31.26 \pm 0.6$ & $35.76 \pm 2.0$ & $40.68 \pm 1.1$ & $44.60 \pm 1.0$ \\
\hline Phosphorus & $76.00 \pm 1.2$ & $115.92 \pm 1.0$ & $122.08 \pm 0.2$ & $128.76 \pm 1.1$ & $129.68 \pm 1.0$ & $131.6 \pm 1.5$ \\
\hline Magnesium & $22.00 \pm 1.4$ & $23.7 \pm 1.2$ & $25.9 \pm 1.0$ & $29.19 \pm 0.2$ & $31.92 \pm 0.4$ & $34.65 \pm 0.8$ \\
\hline Sodium & $200.00 \pm 1.0$ & $194.48 \pm 2.0$ & $192.9 \pm 1.3$ & $183.35 \pm 1.0$ & $177.80 \pm 1.2$ & $172.25 \pm 1.4$ \\
\hline Potassium & $70.00 \pm 2.2$ & $83.27 \pm 1.0$ & $96.5 \pm 0.6$ & $108.45 \pm 1.3$ & $119.7 \pm 1.2$ & $133.22 \pm 1.5$ \\
\hline Copper & $0.02 \pm 0.01$ & $0.41 \pm 0.1$ & $0.79 \pm 0.2$ & $1.19 \pm 0.1$ & $1.58 \pm 0.2$ & $1.96 \pm 0.4$ \\
\hline Zinc & $0.01 \pm 0.00$ & $0.782 \pm 0.01$ & $0.146 \pm 0.06$ & $0.215 \pm 0.03$ & $0.285 \pm 0.04$ & $0.344 \pm 0.01$ \\
\hline Iron & $0.025 \pm 0.00$ & $0.201 \pm 0.1$ & $0.342 \pm 0.2$ & $0.553 \pm 0.4$ & $0.73 \pm 0.1$ & $0.90 \pm 0.2$ \\
\hline
\end{tabular}

${ }^{\star}$ Mean of three replicates.

1- $100 \%$ wheat flour $72 \%$ extraction biscuits (control).

2-3\% tamarind seeds powder supplemented biscuits.

3- $6 \%$ tamarind seeds powder supplemented wheat biscuits.

4- $9 \%$ tamarind seeds powder supplemented wheat biscuits.

5- 12 tamarind seeds powder supplemented wheat biscuits.

6- $15 \%$ tamarind seeds powder supplemented wheat biscuits. 


\section{Egypt. J. of Nutrition and Health Vol. 10 No. 1 (2015)}

Mineral composition of tamarind seeds by-products substituted biscuits $(\mathrm{g} / 100 \mathrm{~g})$ on dry weight basis $(\mathrm{mg} / 100 \mathrm{~g})$ shown in Table (8). The content of calcium, phosphorus, magnesium, potassium, copper, zinc and iron in tamarind seeds by-products substituted biscuits increased with increased the level of addition of tamarind seeds to biscuits. The high content of calcium, phosphorus, magnesium, potassium, copper, zinc and iron $(44.60 \pm 1.0,131.6 \pm 1.5,34.65 \pm 0.8$, $133.22 \pm 1.5,1.96 \pm 0.4,0.344 \pm 0.01$ and $0.90 \pm 0.2 \mathrm{mg} / 100 \mathrm{~g}$ ) respectively in tamarind seeds by-products substituted biscuits with level substitution $15 \%$ of tamarind seeds to biscuits. However, the content of sodium of tamarind seeds byproducts substituted biscuits decreased with increased the level of addition of tamarind seeds to biscuit.

Table (9):

Physical characteristics of seeds tamarind by-product substituted biscuits

\begin{tabular}{|l|c|c|c|c|c|c|c|}
\hline Samples & $\begin{array}{c}\text { weight } \\
(\mathrm{g})\end{array}$ & $\begin{array}{c}\text { volume } \\
\left(\mathrm{cm}^{3}\right)\end{array}$ & $\begin{array}{c}\text { specific } \\
\text { volume } \\
\left(\mathrm{cm}^{3} / \mathrm{g}\right)\end{array}$ & $\begin{array}{c}\text { Width } \\
\text { W } \\
(\mathrm{mm})\end{array}$ & $\begin{array}{c}\text { Thickness T } \\
(\mathrm{mm})\end{array}$ & $\begin{array}{c}\text { Spread } \\
\text { Ratio } \\
(\mathrm{W} / \mathrm{T})\end{array}$ & Spread factor \\
\hline 1 & $41.48 \pm 0.2$ & $67.00 \pm 0.4$ & $1.60 \pm 0.5$ & $36.6 \pm 1.1$ & $7.0 \pm 0.4$ & $5.22 \pm 0.3$ & $100.00 \pm 0.00$ \\
\hline 2 & $39.15 \pm 0.4$ & $69.00 \pm 0.5$ & $1.76 \pm 0.3$ & $36.8 \pm 0.9$ & $7.0 \pm 0.5$ & $5.25 \pm 0.2$ & $100.57 \pm 0.25$ \\
\hline 3 & $36.72 \pm 0.3$ & $59.50 \pm 0.7$ & $1.62 \pm 0.1$ & $36.5 \pm 0.6$ & $6.9 \pm 0.5$ & $5.28 \pm 0.5$ & $101.15 \pm 0.23$ \\
\hline 4 & $36.84 \pm 0.5$ & $61.50 \pm 0.2$ & $1.66 \pm 0.2$ & $36.6 \pm 0.4$ & $6.9 \pm 0.4$ & $5.30 \pm 0.2$ & $101.53 \pm 0.20$ \\
\hline 5 & $37.42 \pm 0.2$ & $54.23 \pm 0.3$ & $1.45 \pm 0.1$ & $36.0 \pm 0.3$ & $7.2 \pm 0.3$ & $5.00 \pm 0.1$ & $95.79 \pm 0.15$ \\
\hline 6 & $38.21 \pm 0.6$ & $49.67 \pm 0.4$ & $1.30 \pm 0.2$ & $36.0 \pm 0.7$ & $7.3 \pm 0.4$ & $4.80 \pm 0.4$ & $91.95 \pm 0.30$ \\
\hline
\end{tabular}

*Mean of three replicates.

1- $100 \%$ wheat flour $72 \%$ extraction biscuits (control).

2- 3\% tamarind seeds powder supplemented biscuits.

3- $6 \%$ tamarind seeds powder supplemented wheat biscuits.

4- $9 \%$ tamarind seeds powder supplemented wheat biscuits.

5- 12 tamarind seeds powder supplemented wheat biscuits.

6- $15 \%$ tamarind seeds powder supplemented wheat biscuits.

Tamarind seeds powder had been considered as a functional food supplement in certain good products because they are reckoned as a good source of dietary fibers, phenolic compounds, minerals and protein. The mean values of physical characteristics of wheat biscuit and fortified wheat biscuits with tamarind seeds powder are presented in Table (9). The data recorded a gradual increment of spread ratio of fortified biscuits with three studied tamarind seeds powders ranging from $5.22 \pm 0.3$ to $5.30 \pm 0.2$ for $3,6 \%$ tamarind seeds powder supplemented biscuits and $9 \%$ tamarind seeds powder substituted biscuits. As results given in Table (9) indicated that specific volume $\mathrm{cm}^{3} / \mathrm{g}$ increased to $1.76 \pm 0.3$, $1.62 \pm 0.1$ and $1.66 \pm 0.2 \mathrm{~cm}^{3} / \mathrm{g}$ for 3,6 and $9 \%$ tamarind seeds powder substituted biscuits; respectively, as compared to the control biscuits without tamarind seed powder which recorded $1.60 \pm 0.5 \mathrm{~cm}^{3} / \mathrm{g}$. 
Asma A. El-Gindy; Mona E. Youssif and Youssif, M.R.G.

Table (10):

Sensory evaluation of seeds tamarind by-products substituted biscuits

\begin{tabular}{|c|c|c|c|c|c|}
\hline Samples & Color & Texture & Taste & Odor & Overall acceptability \\
\hline 1 & $8.3 \pm 0.3^{C}$ & $8.5 \pm 0.5^{B C}$ & $7.5 \pm 0.2^{B}$ & $8.0 \pm 0.2^{C}$ & $8.0 \pm 0.4^{c}$ \\
\hline 2 & $8.5 \pm 0.3^{C}$ & $9.0 \pm 0.3^{A B}$ & $9.0 \pm 0.5^{A}$ & $9.2 \pm 0.2^{A}$ & $8.5 \pm 0.2^{\mathrm{BC}}$ \\
\hline 3 & $9.1 \pm 0.4^{A B}$ & $9.2 \pm 0.3^{A}$ & $9.4 \pm 0.5^{A}$ & $9.5 \pm 0.4^{A}$ & $9.0 \pm 0.4^{A B}$ \\
\hline 4 & $9.4 \pm 0.3^{A}$ & $9.5 \pm 0.3^{A}$ & $9.0 \pm 5.5^{A}$ & $9.6 \pm 0.3^{A}$ & $9.5 \pm 0.4^{A}$ \\
\hline 5 & $9.1 \pm 0.3^{A B}$ & $9.1 \pm 0.2^{A}$ & $9.0 \pm 0.3^{A}$ & $8.5 \pm 0.2^{B}$ & $9.0 \pm 0.3^{A B}$ \\
\hline 6 & $8.6 \pm 0.4^{\mathrm{BC}}$ & $8.0 \pm 0.2^{C}$ & $7.3 \pm 0.3^{B}$ & $8.4 \pm 0.2^{\mathrm{BC}}$ & $8.0 \pm 0.3^{C}$ \\
\hline LSD & 0.5989 & 0.5626 & 0.7153 & 0.4650 & 0.6076 \\
\hline
\end{tabular}

1- $100 \%$ wheat flour $72 \%$ extraction biscuits (control).

2-3\% tamarind seeds powder supplemented biscuits.

3- $6 \%$ tamarind seeds powder supplemented wheat biscuits.

4- $9 \%$ tamarind seeds powder supplemented wheat biscuits

5- 12 tamarind seeds powder supplemented wheat biscuits.

6- $15 \%$ tamarind seeds powder supplemented wheat biscuits.

From the obtained data in table (10) show that sensory evaluation of seeds tamarind by-products substituted biscuits with different levels of tamarind seeds powder showed improvement with the increased level of substitution from 3 until $12 \%$ compared to the control biscuit for all organoleptic characteristics. While, biscuit blended with $15 \%$ tamarind seeds showed lower score in all organoleptic characteristics.

Table (11):

Total phenolic content, total flavonoid content and total antioxidant activity of seeds tamarind by-products substituted biscuits

\begin{tabular}{|c|c|c|c|}
\hline Samples & $\begin{array}{c}\text { TPC } \\
\left(\mathrm{mg} \mathrm{GAE} 100 \mathrm{ml}^{-1}\right)\end{array}$ & 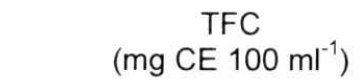 & $\begin{array}{c}\text { TAC } \\
\left(\mathrm{mg} \mathrm{VCE} 100 \mathrm{ml}^{-1}\right)\end{array}$ \\
\hline 1 & $5.44 \pm 1.1$ & $0.00 \pm 0.0$ & $4.12 \pm 0.5$ \\
\hline 2 & $10.55 \pm 0.4$ & $3.89 \pm 0.2$ & $5.22 \pm 0.3$ \\
\hline 3 & $14.63 \pm 0.3$ & $8.93 \pm 0.4$ & $6.95 \pm 0.2$ \\
\hline 4 & $21.01 \pm 0.2$ & $14.67 \pm 0.6$ & $8.33 \pm 0.4$ \\
\hline 5 & $25.23 \pm 1.2$ & $17.98 \pm 0.4$ & $10.01 \pm 0.5$ \\
\hline 6 & $28.87 \pm 0.5$ & $22.43 \pm 0.9$ & $11.13 \pm 0.2$ \\
\hline
\end{tabular}

${ }^{\star}$ Mean of three replicates.

1- $100 \%$ wheat flour $72 \%$ extraction biscuits (control).

2- 3\% tamarind seeds powder supplemented biscuits.

3- $6 \%$ tamarind seeds powder supplemented wheat biscuits.

4- $9 \%$ tamarind seeds powder supplemented wheat biscuits.

5- 12 tamarind seeds powder supplemented wheat biscuits.

6- $15 \%$ tamarind seeds powder supplemented wheat biscuits.

Table (11) shows the total phenolic content, total flavonoid content and total antioxidant activity of seeds tamarind by-products substituted biscuits. The obtainted data shows an increase in total phenolic content of seeds

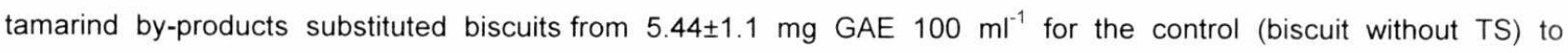
$10.55 \pm 0.4,14.63 \pm 0.3,21.01 \pm 0.2,25.23 \pm 1.2$ and $28.87 \pm 0.5 \mathrm{mg} \mathrm{GAE} 100 \mathrm{ml}^{-1}$ for seeds tamarind by-products substituted biscuits samples containing $3,6,9,12$ and $15 \%$ tamarind seeds respectively. The total flavonoid content (TFC), showed 


\section{Egypt. J. of Nutrition and Health Vol. 10 No. 1 (2015)}

a similar trend, increasing from $0 \mathrm{mg} \mathrm{CE} 100 \mathrm{ml}^{-1}$ for the control to $3.89 \pm 0.2,8.93 \pm 0.4,14.67 \pm 0.6,17.98 \pm 0.4$ and

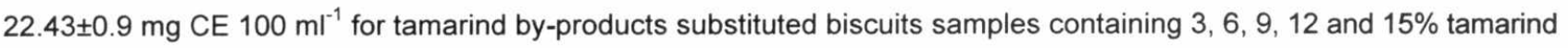
seeds respectively. Similarly, total antioxidant activity increased from $4.12 \pm 0.5 \mathrm{mg} \mathrm{VCE} \mathrm{ml}^{-1}$ for the control to $5.22 \pm 0.3$,

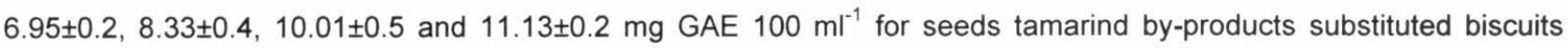
samples containing $3,6,9,12$ and $15 \%$ tamarind seeds respectively.

\section{Conclusions}

The study has further demonstrated experimentally the potential use of $T$. indica L. seed powder in boosting antioxidant activity of tamarind soaked and biscuits as well as enhancing levels of phenolic and flavonoid compounds.

\section{References}

Andabati, B. and Muyonga, J. (2014).

"Phenolic content and antioxidant activity of selected Ugandan traditional medicinal". African Journal of Food Science, 8: 427-434.

AOAC (1997).

Official Methods of Analysis. $16^{\text {th }}$ Ed., Association of Official Analytical Chemists. Arlington-Virginia, USA.

AOCS (1994). Official Methods of American Oil Chemists Society-Champaign. Illinois. USA.

Austin, A. and Ram, A. (1971).

Studies on chapatti making quality of wheat Indian Council of Agricultural Research, New Delhi. Tech. Bullet., 31: $96-101$.

Bhattacharya, S.; Bal, S.; Mukherjee, R. K. and Bhattacharya, S. (1994).

Functional and nutritional properties of tamarind (Tamarindus indica) kernel protein Food Chemistry, 49:19.

Birt D.F.; Hendrich, S. and Wang, W. (2001).

Dietary agents in cancer prevention: flavonoids and isoflavonoids. Pharmacol. Ther. 90:157-177.

Caluwé, E.; Halamová, K. and Van Damme, P. (2010).

Tamarindus indica L. A review of traditional uses, phytochemistry and pharmacology - Afrika Focus 23(1):15383.

Chant, S.R. (1993).

Fables. In: Flowering Plants of the World. Ed. V.H. Heywood.B.T. Batsford Ltd. London.

Chapman, H.D. and P.F. Pratt (1978).

Methods of analysis for soils, plants and waters, Univ. California, Div. Agric. Sci., Priced publication 4034. 
Coronel, R.E. (1991)

Tamanindus indica L. In Plant Resources of South East Asia, Wageningen, Pudoc. No.2. Edible fruits and nuts. (Eds.) Verheij, EW.M and Coronel, R. E., PROSEA Foundation, Bogor, Indonesia: 298-301.

Danial, H.M. and George, C.M. (1979).

Peach seed dormancy in relation to endogenous in inhibitor and applied growth Substances. J.Amer.Soc.Hor.Sc. 97:651-655.

Felker, P. (1981).

Uses of tree legumes in semiarid regions. Economic Botany, 35:174-185.

Felker, P. and Clark, P. (1980).

Nitrogen fixation (acetylene-reduction) and Cross inoculation in 12 prosopis (Mesquite) species. Plant Soil, 57:177-185.

Garba, M.; Yakasai, I.A.; Bakare, M T. and Munir, H.Y. (2003).

Effect of Tamarindus indica L. on the bioavailability of ibuprofen in healthy human volunteers. European Journal of Drug Metabolism and Pharmacokinetics, 28 (3): 179-184.

Gerard, T. (1980).

Tamarind Gum. In R.L Davidson. Handbook of Water Soluble Gums and Resins, Mc Graw Hill Book Co. New York.

Hänsel, R.; Keller, K.; Rimpler, H. and Schneider, G. (1992).

Hagers Handbuch der Pharm. Praxis 5.Auflage Bd 4 Springer Verlag Berlin, Heidelberg, New York p 893.

Jambulingam, R. and Fernandes, E. C. (1986).

Multipurpose trees and shrubs in Tamilnadu state (India). Agroforestry Systems, 4:17-32.

Jia, Z.; Tangm, M. and Wu, J. (1999).

The determination of flavonoid contents in mulberry and their scavenging effects on superoxide radicals. Food Chem.46:555-559.

John, J.; Joy, M. and Abhilash E.K. (2004).

Inhibitory effects of tamarind (Tamarindus indica L.) on polypathogenic fungi. Allelopath J. 14 (1): 43-49.

Kris- Etherton, P.M.; Hecker, K.D.; Bonanome, A.; Coval, S.M.; Binkoski, A.E.; Hilpert, K.F.; Griel, A.E. and Etherton, T.D. (2002).

Bioactive compounds in foods: their role in the prevention of cardiovascular disease and cancer. Am. J. Med. 113:71S-88S.

Larmond, E. (1977).

Laboratory methods for sensory evaluation of food Ottawa, Ontario:food research institute 


\section{Egypt. J. of Nutrition and Health Vol. 10 No. 1 (2015)}

Legesse, M.B. and Emire, S.A. (2012).

Functional and physicochemical properties of mango seed kernels and wheat flour and their blends for biscuit production. Afr. J. Food Sci. 3(9):193-203.

Livesy, G. (1995).

Metabolizable energy of macro-nutrients. Am. J. Clin. Nutr. 62 (Suppl.): 11355-11425.

Lotschert, W. and Reese, G. (1994).

Tropical Plants. Collins Photo Guide. Harper CollinsPublishers:223.

Lu, Y.X.; Zhang, Q.; Li, J.; Sun, Y.X.; Wang, L.Y.; Cheng, W.M. and Hu, X.Y. (2010). Antidiabetic effects of total flavonoids from Litsea Coreana leve on fat-fed, streptozotocin- induced type 2 diabetic rats. Am. J. Chin. Med 38:713-725.

Luengthanaphol, S.; Mongkholkhajomsilp, D.; Douglas, S.; Douglas, P.L.; Pengsopa, L. and Pongamphai, S. (2004).

Extraction of antioxidants from sweet Thai tamarind seed coat: Preliminary experiments. Journal of Food Engineering 63 (3): 247-252.

Mahdavi, R.; Nikniaz, Z.; Rafraf, M. and Jouyban, A. (2010).

Determination and comparison of total polyphenol and vitamin $C$ contents of natural fresh and commercial fruit juices. Pakistan J. Nutr. 9 (10):968 - 972.

Maiti, R.; Jana, D.; Das, U.K. and Ghosh, D. (2004).

Antidiabetic effect of aqueous extract of seed of Tamarindus indica in streptozotocin-induced diabetic rats, Journal of Ethnopharmacology 92 (1): 85-91.

Manohar, R.S. and Rao, P.H. (1997).

Effect of mixing period and additives on the rheological characteristics of dough and quality of biscuit. J. of Cereal Sci., 25: 197-206.

Manthey J.A.; Grohmann, K. and Guthrie, N. (2001).

Biological properties of citrus flavonoids pertaining to cancer and inflammation. Curr. Med Chem. 8:135 - 153.

Marathe, R.M.; Annapure, U.S.; Singhal, R.S. and Kulkami, P.R. (2002).

Gelling behaviour of polyose from tamarind kernel polysaccharide. Food Hydrocol 16 (5): 423-426.

Nwosu, J.N. (2013).

Production and Evaluation of Biscuits from Blends of Bambara Groundnut (Vigna Subterranae) and Wheat (Triticum Eastrum) Flours, International Journal of Food and Nutrition Science, 2 (1): 2165-5316.

Pellet, P.I. and Sossy, S. (1970).

Food Composition Tables for Use in the Middle East. American University of Beirut. Beirut - Lebanon. 
Asma A. El-Gindy; Mona E. Youssif and Youssif, M.R.G.

Popenoe, W. (1974).

Manual of tropical and subtropical. Fruits. Hafner Press, pp: 432-436.

Pugalenthi, M.; Vadivel, V.; Gurumoorthi, P. and Janardhanan, K. (2004).

Comparative nutritional evaluation of little known legumes Tamarindus indica L., Erythrina indica and Sesbania bispinosa. Trop Subtrop. Agroecosyst. 4:107- 123.

Ramos, A.; Visozo, A.; Piloto, J.; Garcia, A.; Rodriguez, C.A. and Rivero, R. (2003).

Screening of antimutagenicity via antioxidant activity in Cuban medicinal plants. J. Ethnopharmacol, 87 (2and3): 241- 246.

Rao, P.S. and Srivastava, H.C. (1974).

Tamarind. In: Industrial Gums. pp. 370-411. Ed. R. L. Whistler, Academic press, Inc. New York.

Sendecor, G.W. and Cochran, W.G. (1987).

Statistical methods (7 Ed.). Ames, IA, USA: The lowa State University Press, pp: 221-222.

Shankaracharya, N.B. (1998).

Tamarind - Chemistry, Technology and Uses - a critical appraisal. Journal of Food Technology, 35 (3): $193-208$.

Siddhuraju, P. (2007).

Antioxidant activity of polyphenolic compounds extracted from defatted raw and dry heated Tamarindus indica seed coat. Food Sci. Technol- LEB. 40:982-990.

Stross, A.E. (1995).

Know your trees. Some common tress found in Zambia. pp. 204-208. Regional Soil Conservation Unit. (RSCU). Zambia.

Tapas, A.R.; Sakarkar, D.M. and Kakde, K.B. (2008).

Flavonoids as nutraceuticals: A review. Trop. J. Pharm. Res. 7 (3):1089- 1099.

Thimmaiah, S.K. (1999).

Standard Methods of Biochemical Analysis. New Delhi, India: Kalyani Publishers. 
Egypt. J. of Nutrition and Health Vol. 10 No. 1 (2015)

دراسات كيماوية واستخدام التمر الهندى وبذوره فى بعض التطبيقات التكنولوجية

اسمة الجندي، مني السيا يوسف السيا و محمد رشاد جودة يوسف

معهد بحوث تكنولوجيا الأغذية، مركز البحوث الزراعية، الجيزة، مصر ولئر

الملخص العربى

التمر الهندي هو ثمرة مغذية وله استخدامات متتوعة. وتم دراسة خصائصه على نطاق واسع ، مع الإشـارة إلى مكونات البذور.

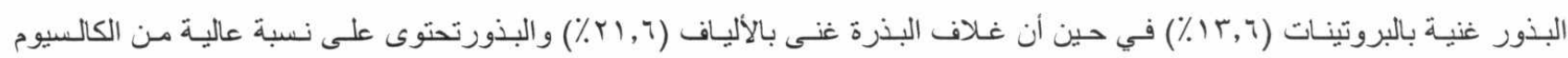

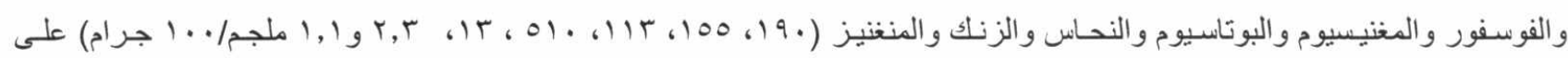

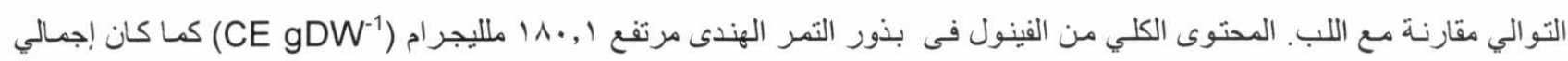

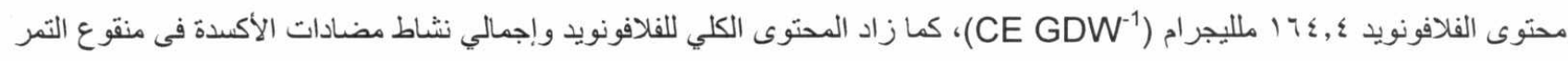
الهندى المضاف له مسحوق بذور التمر الهندى مقارنة مع الكنترول (منقوع التمر هندي دون مسحوق بذور التولى التمر الهندى). أيضا، إضـافة مسحوق بذور التمر الهندي إلى منقوع التمر هندي لمستوى ب٪ (وزن / حجم) لم تسفر عن أب اختلاف كبير في الصفات الحسية بالمقارنة

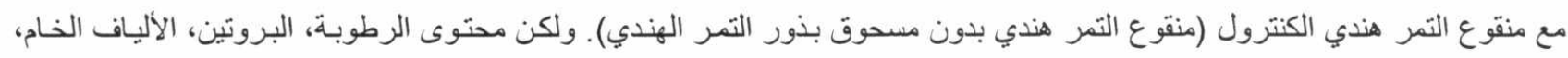

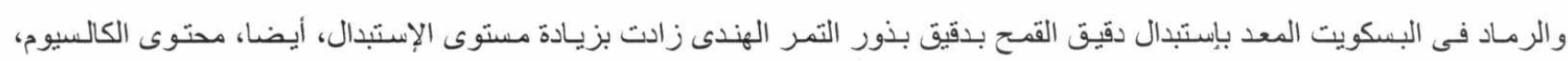

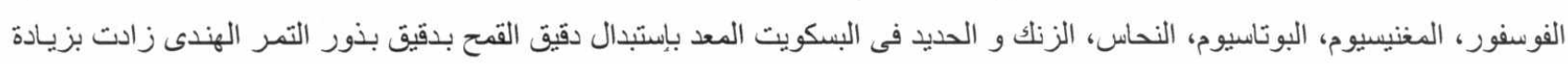

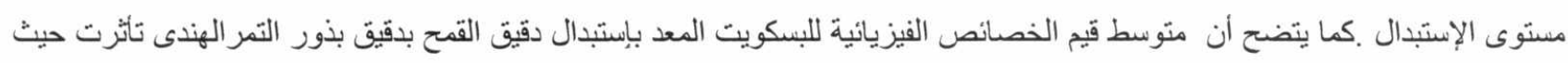

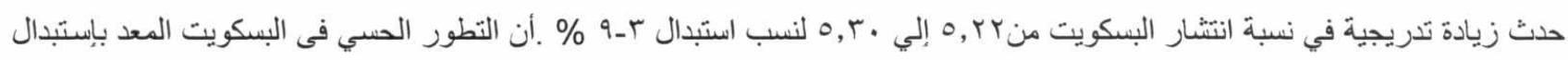

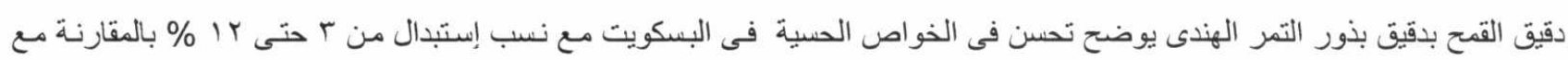

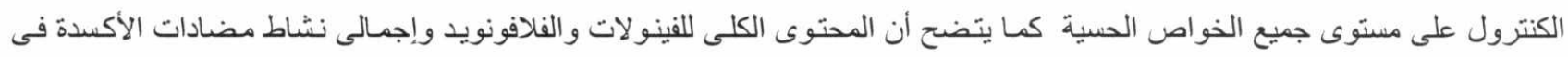
البسكويت المعد بإستبدال دقيق القمح بدقيق بذور التمر الهندى زادت بزيادة مستوى الإستبدال.

الكلمات الدالة: بذور التمر هندي - عصبر التمر هندي ـ الفينولات الكلية ـ الفلافونديدات و مضادات الاكسدة الكلية ـ منقوع التمر هندي البسكويت. 